\title{
School Heads of Departments' Roles in Advancing Science and Mathematics through the Distributed Leadership Framework
}

\author{
Paul Nwati, Munje \\ University of the Free State, Bloemfontein Campus, South Africa \\ https://orcid.org/0000-0002-7948-9704 \\ Maria, Tsakeni \\ University of the Free State, Qwaqwa Campus, South Africa \\ https://orcid.org/0000-0003-3208-1362 \\ Loyiso C., Jita \\ University of the Free State, Bloemfontein Campus, South Africa \\ https://orcid.org/0000-0001-6871-6820
}

\begin{abstract}
The prioritization of quality education, especially in science and in mathematics, positions effective teaching and learning as a major school leadership goal. Effective curriculum implementation hinges on power dynamics in schools; this puts distributed leadership in the spotlight. Heads of departments (HoDs) are important role players in the distributed leadership structures of schools. This qualitative case study explored the roles of HoDs in four South African high schools to determine how opportunities were created for teaching and learning science and mathematics in the context of distributed leadership. Unstructured interviews were conducted with 13 participants. The findings show that, in distributed leadership structures, HoDs in science and mathematics played the roles of instructional leaders; school-based subject and classroom specialists; and that they were accountable for learner performance in their departments. Their actions supported other players in school leadership, including teachers in the classroom and principals, to improve teaching and learning through distributed leadership structures. We recommend that further studies explore and compare how HoDs navigate the complexities of their roles in different school contexts.
\end{abstract}

Keywords: Distributed leadership; Head of Department; Professional development; Science and mathematics 


\section{Introduction}

The positive outcome of the relationship between effective school leadership and school improvement is currently embedded in education policies and research across the globe (Botha \& Triegaardt, 2014; Harris, 2003; Harris, 2013; Harris \& Spillane, 2008; Harris, Day, Hopkins, Hadfield, Hargreaves \& Chapman, 2013; Leithwood, Harris \& Hopkins, 2020). The positive outcome emanates from the influence of school leaders on learning outcomes. This claim aligns with the assertion that ineffective leadership is one of many factors that contribute to underperformance in South African public schools (Kirori \& Dickinson, 2020). In effect, poor instructional leadership could be among the causes of poor performance in a school (Seobi \& Wood, 2016). The significance of this assertion explains why teacher leadership is increasingly becoming prominent in research that focuses on school improvement initiatives (Bipath \& Nkabinde, 2018; De Lima, 2008). In recent years, the focus has been on distributed leadership, because it allows different voices to prevail in the leadership structure and to use a variety of human capital in a school to achieve a common goal. Rather than attributing school successes to the heroic acts of individuals, distributed leadership allows the roles and contributions of all other actors to be considered and recognized (Spillane, 2006). Unlike traditional notions of leadership that is "premised upon an individual managing hierarchical systems and structures, distributed leadership is a form of collective leadership in which teachers develop expertise by working collaboratively" (Harris, 2003, p.11). The roles of every individual, both formal and informal, are resources that contribute significantly to the achievement of set goals (Harris \& Spillane, 2008). According to Bush (2018a), distributed leadership provides an opportunity to empower teachers in developing their leadership capabilities. Therefore, it is important to recognize what teachers, heads of departments (HoDs), deputy principals and principals do in their capacities and collectively to contribute to school improvement. Hence, this study explored HoDs' roles in advancing science and mathematics through the distributed leadership framework.

It is important to explore and to understand more about the leadership practices of HoDs in the distributed leadership structures and to understand the impact of their daily activities on the improvement of teaching and learning in science and mathematics. Spillane, Halverson, and Diamond (2001, p. 24) noted that "leadership involves the identification, acquisition, allocation, coordination, and use of the social, material, and cultural resources necessary to establish the conditions for the possibility of teaching and learning." This assertion justifies our focus on the roles undertaken by HoDs to enhance opportunities for science and mathematics teaching and learning in selected South African high schools. This claim is also a response to the plea by Spillane et al. (2001) for more inquiry that deviates from school leadership structures as such, to interrogate and to understand leadership as a practice which, according to Raelin (2016), is not about the traits and behaviors of particular individuals, but about what should occur in practice. Raelin (2016) sees leadership as a collective effort that aims to accomplish a common goal; it is not merely about what an individual thinks and does. Therefore, the study focused on exploring this practicality in selected South African high schools. 
In South Africa, there is growing evidence that schools make use of distributed leadership structures that vary in effectiveness (Sibanda, 2017). Regarding science and mathematics, Tsakeni and Jita (2017) highlighted the role of teachers, who have traditionally been regarded as followers of school leadership for classroom improvement. This resonates with Leithwood et al. (2020) who guide us to investigate what HoDs do as curriculum leaders and not to explore the practice of distributed leadership itself. We ask the following question: Which roles do HoDs play to advance science and mathematics teaching and learning in selected South African high schools?

\section{Literature review}

Considering the link between science, mathematics, and employability, and the impact of mathematics on the workplace (Durrani \& Tariq, 2012), efforts are being made to improve its teaching and learning globally and in South Africa. However, poor performance in mathematics in South Africa is, for example, cause for concern. This prompts research and policy initiatives on ways to improve teaching and learning (Nel \& Luneta, 2017). To ensure an improvement in the teaching and learning of school subjects, including mathematics, instructional leadership becomes paramount (Zuze \& Juan, 2018). However, Zuze and Juan (2018, p. 459) caution that there are "distinct relationships between school leadership and management and academic achievement based on the socio-economic status of learner bodies."

Notably, due to the rapidly changing nature of the school environment characterized by increasing student enrolment and increasing workload (Harris \& Spillane, 2008; Samancioglu et al., 2020), principals are progressively delegating powers to deputy principals and particularly to HoDs, who direct and monitor instruction (Rosenfeld, Ehrich \& Cranston 2009. The delegation of key roles to HoDs is part of the drive by the South African education system to improve teaching and learning (Bambi, 2012). Patterson et al. (2020) consider that this drive could rewrite a school's performance history provided that it is implemented effectively. In an attempt to emphasize the roles of HoDs, Syomwene (2018) identified educational supervision and leadership as ingredients that are instrumental in ensuring quality curriculum implementation. HoDs, as specialists in the subject areas in which they play leadership roles, are expected to direct and monitor instruction, which includes providing relevant support and guidance to teachers (Mpisane, 2015; Syomwene, 2018). HoDs are expected to provide motivation and to act as role models for teachers by establishing good interpersonal and working relationships (Bipath \& Nkabinde, 2018; Ogina, 2017).

Theoretically, HoDs have a great responsibility to monitor and supervise instruction, though this is not the case in all school contexts (Weller Jr, 2001). Mokoena (2017, p. 284) reported that HoDs perform multiple roles in their quest to ensure effective curriculum delivery, of which some are visible in various school contexts. Some of these roles involve inquiry-based decisions, reflective practice, and broad-based skillful collaboration. Although the actual impact of supervising instruction could be debatable, there is no doubt that, when 
properly conducted, it can have a positive influence on learner performance (Ankoma-Sey \& Maina, 2016; Patterson et al., 2020), on teacher professional practices, and on school climate (Abreh, 2018; Ma \& Marion, 2019). However, this is only possible when supervision is used to identify impending challenges, to provide relevant guidance and support, and not as a punitive apparatus (Mpisane, 2015; Syomwene, 2018).

Fundamentally, HoDs perform administrative and pedagogic roles to improve learner performance in specific subjects-roles that are distinct in successful schools (Farchi \& Tubin, 2019). Based on a Portuguese experience, De Lima (2008, p. 163) identifies three major roles of HoDs, namely: (1) ensuring curriculum integration through the promotion of cooperation among department members, and between the department and other organizational units of the school; (2) ensuring the coordination of department members' pedagogy and student assessment practices; and (3) identifying department members' training needs and promoting their adequate school-based in-service training.

The phenomenon of teacher leadership which is embedded in the distributed leadership framework became prominent in South Africa after 1994. Teacher leadership was intended as a strategy to democratize schools and to introduce a collaborative approach to school management; it was regarded as a tool that could transform South African schools in the new democratic dispensation (Grant, 2016). The journey towards participatory decision-making in schools, despite its gains, was marred by several challenges, among which were power struggles (Mncube, 2009; Mokoena, 2011). Principals saw themselves "as managers and not as instructional leaders" (Taole, 2013, p. 75). Recent research shows that distributed leadership practices are visible in well-resourced and under-resourced South African schools (Du Plessis, 2016). Distributed leadership gives HoDs, as instructional leaders, the authority to prioritize the monitoring of teachers' duties. Nel and Luneta (2017) identify the following consequences of teacher monitoring: an improvement in the way mathematics content is disseminated, better instructional and lesson planning skills, and more teacher collaboration. The foregoing discussions indicate that considerably more needs to be known about distributed leadership; hence we contribute to the ongoing discourses by exploring the roles played by HoDs to advance the teaching and learning of science and mathematics in selected South African high schools.

\section{Theoretical framework}

This paper uses a theoretical lens that defines distributed leadership as an interactive web consisting of leaders, followers, and the situation (Spillane, Halverson \& Diamond, 2004). According to Spillane et al. (2004), leadership does not reside in any of these three components, but the components viewed together facilitate the process of leadership. Therefore, coming from a perspective where school leadership is not considered to be centered on individuals, Spillane et al. (2004) define distributed leadership as a practice that involves leaders, followers, and their situation. In this paper, leadership is distributed among science and mathematics HoDs, who exert influence in their 
departments; on the teachers (the followers); on other stakeholders, such as positional leaders in the school; and on the situation, which is to advance teaching and learning in the science and mathematics classrooms. This distributed leadership structure enabled the exploration of interactions among the HoDs, the teachers, and other stakeholders, and the process of improving teaching and learning in science and mathematics. Despite the significance of distributed leadership in education establishments and its potential for implementation (sometimes informally in different spaces with immeasurable results), its complete recognition and application are still to be fully realized. Hence, Spillane et al. (2001) advocated more research that will help us to understand how distributed leadership structures influence the day-to-day running of schools. However, the process needs to deviate from concentrating on definitions and perceptions of distributed leadership, to exploring actual leadership practices in schools (Harris, 2003). This explains why Thorpe et al. (2011, p. 241) argued that distributed leadership should emphasize "conjoint actions rather than role or position." Van Ameijde et al. (2009, p. 766) added that "leadership is a shared influence process to which several individuals contribute [and] ... arises from the interactions of diverse individuals which together form a group or network in which essential expertise is a dispersed quality."

At the core of distributed leadership should be how and why school leaders, including HoDs, do certain things (Spillane et al., 2001) and their implications. In this paper, the focus is on what HoDs do to enhance school improvement. Effective distributed leadership prevails when what is shared is identifiable and has glaring implications, not only for those working at schools (including teachers) but also for school outcomes and learner performance (Harris, 2013). In retrospect, effective curriculum implementation reflects how well HoDs perform their duties to monitor and to direct instruction. Owing to the positive impact of distributed leadership, teacher motivation and job satisfaction are some of the expected outcomes (Samancioglu et al., 2020), although distributed leadership is not a "magic potion" for all the challenges faced by individual schools (Harris, 2003).

It is important to note that unique and unavoidable factors may affect the outcomes of the distributed leadership roles exhibited by HoDs in individual school spaces. Bambi (2012) noted that the expected roles of HoDs may be actualized in different ways, due to the uneven power distribution in some school contexts. Hence, Christie et al. (2010) argued that context is among the factors which influence leadership effectiveness and school organizational capacity. Such assumptions do not mean that schools experiencing socioeconomic challenges cannot implement distributed leadership effectively.

\section{Method}

This qualitative case study researched the phenomenon (Creswell, 2014) on roles that school HoDs play to promote science and mathematics through the distributed leadership framework. This phenomenon was explored through data collected during unstructured interviews in four high schools. Two of these schools were suburban and two were township schools selected for 
triangulation. Although the interview questions were not prearranged, the researchers referred to common themes that emerged from the literature to generate open-ended questions. These were followed up by probing to generate data that consisted of in-depth and thick descriptions by the participants (Mathers et al., 1998). The suburban schools were located in a high socioeconomic status neighborhood in the Tshwane South district of South Africa. The two township schools were selected from neighborhoods of low socioeconomic status in Tshwane West. The inclusion of schools from the low socio-economic district provided an opportunity to understand how distributed leadership is implemented in disadvantaged schools that also face other leadership challenges (Sibanda, 2017). The study was delimited by the choice of a qualitative case study design that focused on a phenomenon that was explored through the use of the four high schools selected from the city of Tshwane in South Africa, as described above. Although the findings of this study contribute to the literature on the role of HoDs in science and mathematics classroom improvement, they cannot be generalized.

Unstructured interviews are appropriate for exploring complex human experiences (Zhang \& Wildemuth, 2009). The unstructured interviews were guided by questions related to the following topics: (1) monitoring instruction, (2) ensuring improved classroom practice in science and mathematics, (3) providing support to science and mathematics teachers, and (4) the roles of HoDs in the broader distributed leadership structures of the schools. Table 1 provides a summary of indicators and key questions that were used as probes.

Table 1: Summary of interview schedule indicators and key questions

\begin{tabular}{|l|l|}
\hline \multicolumn{1}{|c|}{ Indicators } & \multicolumn{1}{|c|}{ Key questions } \\
\hline (1) Monitoring instruction & $\begin{array}{l}\text { Question 1: Which processes are put in place to make sure that } \\
\text { teaching and learning are effective in science/ mathematics } \\
\text { classrooms? } \\
\text { Question 2: Who is responsible for making sure that teaching } \\
\text { and learning are effective in science/ mathematics classrooms? } \\
\text { Which monitoring tools are used? Which roles do HoDs play? }\end{array}$ \\
\hline $\begin{array}{l}\text { (2) Ensuring improved } \\
\text { classroom practice in science } \\
\text { and mathematics }\end{array}$ & $\begin{array}{l}\text { Question 3: What does the school do to improve the teaching } \\
\text { and learning of science and/or mathematics? } \\
\text { Question 4: Who is responsible for the improvement of } \\
\text { teaching and learning? What are the specific roles of the people } \\
\text { who are responsible for the improvement of teaching and } \\
\text { learning? }\end{array}$ \\
\hline $\begin{array}{l}\text { (3) Providing support to } \\
\text { science and mathematics } \\
\text { teachers }\end{array}$ & $\begin{array}{l}\text { Question 5: What kind of support is available to teachers for } \\
\text { teaching science and mathematics? } \\
\text { Question 6: Who provides support? } \\
\text { Question 7: How often is the support provided? Is the support } \\
\text { sufficient? }\end{array}$ \\
\hline $\begin{array}{l}\text { (4) The roles of HoDs in the } \\
\text { broader distributed leadership } \\
\text { structures of the schools. }\end{array}$ & $\begin{array}{l}\text { Question 8: What are the duties and the roles of science and } \\
\text { mathematics HoDs in the school? } \\
\text { Question 9: How do science/mathematics HoDs support the } \\
\text { teaching and learning of science and mathematics? } \\
\text { Question 10: How are the science/mathematics HoDs } \\
\text { supported by other stakeholders at the school as they lead their } \\
\text { departments? }\end{array}$ \\
\hline
\end{tabular}


The 13 participants were allowed to provide narratives freely and emerging issues were followed up using cues (Mathers et al., 1998). Through the purposeful sampling technique, 13 participants from the four schools, which are identified as schools A, B, C, and D, were approached; they agreed to take part in the study and they were interviewed. The participants were chosen because they formed part of the distributed leadership structures of the schools in the teaching of science and mathematics. The criteria, therefore, suited the exploration of the phenomenon and therefore the focus was not necessarily the characteristics of the participants. Table 2 presents the 13 participants in the study and the criteria for selection.

Table 2: Participant summary and selection criteria

\begin{tabular}{|c|c|c|}
\hline School & Participants & Criteria for selection \\
\hline \multirow[t]{4}{*}{$\begin{array}{l}\text { A } \\
\text { Suburban }\end{array}$} & Principal & $\begin{array}{l}\text { Positional leader and part of the distributed } \\
\text { leadership structure }\end{array}$ \\
\hline & Mathematics teacher & $\begin{array}{l}\text { Subject teacher and part of the distributed leadership } \\
\text { structure }\end{array}$ \\
\hline & $\begin{array}{l}\text { Physical Science } \\
\text { teacher }\end{array}$ & $\begin{array}{l}\text { Subject teacher and part of the distributed leadership } \\
\text { structure }\end{array}$ \\
\hline & $\begin{array}{l}\text { Science and } \\
\text { Mathematics HoD }\end{array}$ & $\begin{array}{l}\text { Department leader, subject teacher, and part of the } \\
\text { distributed leadership structure }\end{array}$ \\
\hline \multirow[t]{4}{*}{$\begin{array}{l}\text { B } \\
\text { Suburban }\end{array}$} & Principal & $\begin{array}{l}\text { Positional leader and part of the distributed } \\
\text { leadership structure }\end{array}$ \\
\hline & Mathematics teacher & $\begin{array}{l}\text { Subject teacher and part of the distributed leadership } \\
\text { structure }\end{array}$ \\
\hline & $\begin{array}{l}\text { Science and } \\
\text { Mathematics HoD }\end{array}$ & $\begin{array}{l}\text { Department leader, subject teacher, and part of the } \\
\text { distributed leadership structure }\end{array}$ \\
\hline & $\begin{array}{l}\text { Physical Science } \\
\text { teacher }\end{array}$ & $\begin{array}{l}\text { Subject teacher and part of the distributed leadership } \\
\text { structure }\end{array}$ \\
\hline \multirow[t]{2}{*}{$\begin{array}{l}\text { C } \\
\text { Township }\end{array}$} & Deputy principal & $\begin{array}{l}\text { Positional leader and part of the distributed } \\
\text { leadership structure }\end{array}$ \\
\hline & $\begin{array}{l}\text { Science and } \\
\text { Mathematics HoD }\end{array}$ & $\begin{array}{l}\text { Department leader, subject teacher, and part of the } \\
\text { distributed leadership structure }\end{array}$ \\
\hline \multirow[t]{3}{*}{$\begin{array}{l}\text { D } \\
\text { Township }\end{array}$} & Principal & $\begin{array}{l}\text { Positional leader and part of the distributed } \\
\text { leadership structure }\end{array}$ \\
\hline & Deputy principal & $\begin{array}{l}\text { Positional leader and part of the distributed } \\
\text { leadership structure }\end{array}$ \\
\hline & $\begin{array}{l}\text { Science and } \\
\text { Mathematics HoD }\end{array}$ & $\begin{array}{l}\text { Department leader, subject teacher, and part of the } \\
\text { distributed leadership structure }\end{array}$ \\
\hline
\end{tabular}

Textual data were generated from the participants' narratives. The data were analyzed through conventional qualitative content analysis techniques which entailed several steps starting with the reading of the data texts, putting labels on the texts (open-coding), and grouping emerging concepts into larger clusters called categories. The categories were furthermore grouped into themes that emerged from the data (Hsieh \& Shannon, 2005). The frequent mention of the role played by HODs to ensure that the curriculum policy was adhered to in science and mathematics teaching and learning, resulting in the emergence of 
the theme, "curriculum implementation guidance." The use of the four topics in Table 1 in an unstructured manner allowed for inductive data analysis from which themes emerged, as explained above.

\section{Findings and discussions}

This section presents and explains the findings. The paper explored the roles played by HoDs in promoting the teaching and learning of science and mathematics in selected South African high schools. Findings show that distributed leadership provided room for accountability in the teaching and learning situation, as teachers had to report to HoDs and, in turn, HoDs had to report to either a deputy principal or to a principal. Therefore, HoDs paid attention to what teachers did and found ways and means to assist them to do better since teachers' performance was a critical aspect in HoD reports. These findings contribute to existing literature advocating schools' serious engagement in distributed leadership practices, which is based on advantages accrued from the convergence of human capital, effective monitoring, and supervision of instruction. Three main themes emerged from the findings: (1) curriculum implementation guidance, (2) monitoring of instruction and forging collaboration, and (3) teacher professional development.

\subsection{Curriculum implementation guidance}

Curriculum implementation constitutes the core function of school HoDs (Atieno et al., 2018) who daily engage with teachers. Curriculum implementation in the classroom is the yardstick of success for any education policy initiative. The HoD for mathematics and sciences at School $\mathrm{C}$ explained how HoDs are instrumental in curriculum implementation to ensure that policy expectations are met:

It is to see to it that the syllabus as prescribed by the Department is covered and that the educators are comfortable with the subject they are teaching, and to check their performance and to analyze their performance. Analyze the results and see where there is a need for intervention - that is my role. (HoD, School C)

Interventions assisted HoDs in identifying challenges faced by teachers and in providing alternative solutions by using varied mechanisms to ensure smooth curriculum delivery. The HoD at School B shared similar sentiments about the value of interventions to ensure the standardization of content knowledge, to smooth lesson delivery, and to improve classroom practices. The HoD said that intervention is,

to look at the standard of teaching and learning of everybody, I must make sure that all the teachers know the content, they can discipline the learners and empathize with the learners... the standards of learning is very important so the whole story is [on] a high standard and that is about it. (HoD, School B)

Different approaches to curriculum implementation emerged from diverse school contexts. The mathematics teacher at School A revealed that the HoD had established formal and informal structures to check the pulse of individual teachers regarding curriculum implementation. This teacher, however, 
cautioned that the HoD's supervision machinery focused more on teachers teaching Grade 12 since these teachers engaged in more revision activities to prepare learners for their exit level examinations. Furthermore, the mathematics teacher at School A explained how the HoD had intensified the monitoring and supervision of instruction in Grades 11 and 12 to improve learner performance:

If we are teaching Grades 11 and 12, it's a must every day, before we go to teach this concept every day you report to the office to indicate how far you are with a concept, if we are behind the HoD may ask you to do extra classes. But that only happens when we are teaching Grade 11 and 12. (Mathematics teacher, School A)

When HoDs are constantly in touch with teachers, HoDs are alert and they are informed by feedback from teachers about what they do or fail to do in the classroom. Being informed is important because teachers are autonomous in their classrooms but accountable to the HoD, whose intervention creates room for efficacy (see McLean, 2013; Van Ameijde et al., 2009). Since HoDs are specialists in the subjects that they lead, their competence advantages them to determine whether teachers are on track or whether they are demonstrating deficiency and need assistance. Syomwene (2018) and Vanblaere and Devos (2018) corroborate that when HoDs monitor and coach teachers in specific subject areas, there is accountability and the likelihood of positive implications for teacher quality, improved classroom practices, and learner performance. Besides, when teachers report to HoDs before lessons, it ensures accountability (Harris, 2005; McLean, 2013). Consequently, it becomes easy for the HoD to know when a teacher is absent and to arrange for a replacement. The HoD at School $\mathrm{C}$ provided evidence of how absent teachers were replaced by checking the timetables of all the teachers present in the discipline to establish their availability during that period. One of the HoD's jobs was to find replacement teachers in times of need:

I go to that class, or I check the timetables - because I always have the timetables for other teachers from my department. I will just see during that period if any teachers are free, then we will request a teacher to go and replace the teacher. $(\mathrm{HoD}, \mathrm{School} \mathrm{C})$

However, the HoD explained that in critical situations, where a substitute teacher with expertise in the specific subject area was unavailable due to timetable clashes, they adopted the peer teaching methodology to ensure that learning took place. In this case, any other teacher at the school would go to the classroom to "babysit" the learners and to ensure that those learners continue working in the subject while teaching one another in the process. The impact of this approach on curriculum implementation speaks for itself when compared to a situation analysis of a scenario in School D, where negative consequences caused by a lack of intervention were obvious. The physical science teacher at School D said:

Teachers sometimes might not [be] there in class then learners will start to relax when we get into the class when they haven't done anything, it's a little difficult for them to make sense of the subject matter by themselves. (Physical science teacher, School D). 
Also, HoDs supported curriculum implementation by ensuring that teachers integrate technology when they delivered their lessons. Syomwene (2018) considered technology as fundamental in an era where constant technological advance warrants increased teacher adaptability in the classroom. The HoD at School B elucidated:

We use laptops and projectors here so I see to it that everything is intact, ensuring that all learners in a grade get the same work, the same slides which they show [to] the children and their homework that they have to do...we send each other emails or even Whatsapp. (HoD, School B)

Efforts such as these indicate how HoDs as instructional leaders in distributed leadership structures contributed to promoting opportunities for teaching and learning in science and mathematics.

\subsection{Monitoring instruction and forging collaboration}

Monitoring instruction is an important tool that guarantees effective teaching and learning; monitoring manifests in the form of informal or unplanned class visits (Mpisane, 2015). HoDs used classroom visits to observe what teachers did and to identify possible gaps that required their assistance. HoDs were specialists in the subject areas in which they served as instructional leaders (Spillane et al., 2001; Syomwene, 2018). The HoD at School C clarified the use of relevant skills to monitor and direct teachers in achieving subject-specific objectives:

If work is not done, there must be a reason why this was not done. You have to find out why what are the challenges, why was this not done?...If according to the syllabus, we are supposed to be at week 10 and the teacher according to the work schedule - [and] according to the work brochure, [it] is in week eight, the teacher must account [on] what happened to those two weeks. (HoD, School C)

This explanation aligns with the assertion that HoDs can determine the level of teacher planning and identify impending challenges by observing lesson delivery during class visits (Ampofo et al., 2019). Accordingly, they create spaces for improvement.

In the context of distributed leadership, the collaboration aims to filter down leadership responsibilities to teachers, who are generally expected to exercise some form of autonomy in their classrooms. A collaborative process promotes peer mentoring among teachers. This process also leads to accountability, which guides the route to educational performance (Harris, 2005). Accountability guarantees an improvement in teaching and learning. Although the HoD for science at School B had such a heavy administrative and teaching load (see Mashapa, 2019) that he could only visit each teacher twice a year, arrangements for teacher-teacher class visits existed as a form of collaboration and encouragement among teachers. Following this arrangement, each teacher needed to be visited by a colleague eight times a year. Teachers reported that they had reaped immeasurable benefits. This procedure is consistent with Spillane's (2001, p. 27) view of distributed leadership in a school context. He stated that "efforts to improve instruction that target more interactions among 
more elements of the instructional unit may be more effective." Hence, Syomwene (2018) encourages the use of class visits as a developmental opportunity for teachers, not for fault finding. However, even when the intention is not fault-finding, some teachers are suspicious and uncooperative, as is the case in some South African schools (Du Plessis, 2016).

However, the HoD at School C declared that when teachers fail to do their work, a harsh tone is required "to find out what were the reasons." This approach does not question teacher capacity nor does it take away their autonomy. Instead, it intends to ensure the requisite accountability for effective, distributed leadership. Participants reported that class visits generally improved teaching and learning because they constantly put them under pressure to keep up with work demands to avoid queries from management. It is noteworthy that the pressure caused by class visits also helped teachers to develop professionally; an idea that aligns with Mpisane (2015). Teacher output is likely to increase when HoDs intensify the monitoring and supervision of lesson planning processes and delivery through class visits (Ampofo et al., 2019). Evidence confirms that, when teachers' lesson plans are not monitored, laxity may set in with negative consequences to the quality of teaching and learning (Munje, 2018).

Furthermore, when teachers agree and collaborate, they share knowledge and find themselves on the same page. Thus, standardization is ensured as a viable way to raise teaching and learning standards at schools (Harris, 2005). The multiple roles of HoDs include forging collaborative engagements among teachers that assist in developing their collective expertise (Harris, 2003). De Lima (2008) considers this a sign of effective distributed leadership, which is visible in schools where quality education is a priority (Mpisane, 2015). The HoD for mathematics at School A corroborated this claim:

I will tell them today we do this, and we have the same textbook and we have the same lessons. But you are not allowed if you've got Grade [twelves'] to do something with your learners and you don't tell other Grade 12 teachers, you are not allowed to give them examples if you don't present to other teachers, so we work very closely together. (HoD, School A)

Additionally, in an attempt to monitor and support instruction, HoDs assist teachers to resolve classroom challenges, including learner misconduct. The HoD at School C explained: "There are many challenges inside the classrooms, where some learners are not well behaved. So, if they report such learners, we have to take steps and then assist.....

The supposition is that such intervention measures indicated the existence of accountability at the school, which is an important element of distributed leadership, and confirmed the authority of teachers in the classroom. The HoD at School C further explained:

They don't report every case, some things they must be handled as class teachers in class, but they only report cases which they can't handle in class. For instance, if a learner is continuously late if a learner is continuously not doing their work. They bring such learners to me...I 
try to find out the reasons why the learners are behaving that way. (HoD, School C)

This HoD reiterated that in situations where interventions aimed at resolving learner misconduct failed, they had solicited parental assistance, often with impressive results. Common causes of learner misconduct included late coming and failure to do homework.

Similarly, HoDs monitored teachers to ensure that those teaching the same grades and specific subjects were on the same page. The HoD for science at School B saw this as a form of standardization, "I check their assessment tasks, pre-moderation, and post-moderation and I make sure that everything is [on a] standard." The role of the HoD, therefore, is to ensure that there is accountability and that teachers are in line with the program set for the completion of the syllabus (Bush, 2018b). Besides, the principal at School D explicated a trend of checks and balances that was aimed at ensuring standardization among teachers, which could lead to improved learner performance:

They must check if the teacher has some challenges and give them support ... to see the work of the children and make sure that [the] teacher relates well [with] the students, and there is a successful outcome from the teacher-learner relationship in the classroom, in terms of the learner results in the class. The HoD has to support the teachers and to moderate their work. (Principal, School D)

The HoD at School C corroborated that such interventions have the potential to provide a positive direction for teaching and learning because constant checks conducted by teachers, who teach similar grades and subjects, ensure content alignment and standardization. HoDs also checked teachers' files to ensure efficacy. The deputy principal at School $\mathrm{C}$ explained that controlling educators' files gave HoDs a better understanding of how teachers did their daily planning, of their preparedness and effectiveness during lessons, and of learners' results, which ought to be a true reflection of good planning and lesson delivery. From this information, HoDs were able to determine teachers' successes, challenges, and the nature of assistance required individually or collectively. Ampofo et al. (2019) support the supervision of teachers' planning by HoDs because planning is an individual responsibility that has a great deal of influence on teaching and learning (Naicker \& Mestry, 2013).

In addition to monitoring and directing instruction, HoDs also played a coordinating role, by acting as coordinators between teachers, deputy principals, and principals to ensure effective curriculum implementation and an improvement in learner performance (Du Plessis \& Eberlein, 2018; Harris, 2003). Hence, when HoDs are unable to resolve certain challenges faced by teachers, they ask for the assistance of deputy principals. This is usually only needed when they have exhausted all alternative avenues to resolve the problem. The $\mathrm{HoD}$ at School C reported:

We check the teachers' work and when we are aware of some of the challenges, we call the teacher. Then we advise and we recommend what 
could be done. But sometimes if the problem persists, that is when we involve the deputy principal - as to say - this is how far I've gone with this teacher, but there is nothing we are achieving, can you assist? (HoD, School C)

Furthermore, this HoD explained how collaboration with the principal overcomes unforeseen setbacks that are, for example, caused by teacher absenteeism. He indicated that "[i]f there is a teacher in your department who is not in, you have to report to your principal ... so that we can find a replacement." This procedure offers evidence that distributed leadership does not render those in formal leadership roles redundant, as they are required to oversee the overall functionality of the institution through certain forms of interventions to "hold the pieces together" (Harris, 2003, p. 11).

It is worth noting that the ability of HoDs to successfully monitor and support instruction in schools is based on their accessibility. The physical science teacher at School B commented that the HoD's open-door policy created supportive spaces for effective curriculum implementation: "We have meetings every week with her ... her door is always open for any problem or questions. Every time we have a problem, we go to her. So, she is there in a supportive role for us." Similar sentiments about the HoD's role were echoed by the mathematics teacher at School B: "Whatever you need, he is fantastic, he helps us a lot and we meet every Thursday morning and in that meeting, we will ask anything and he is just ready to help." This sentiment reiterates the role of HoDs in supporting instruction despite their multiple responsibilities.

Because HoDs also teach, they make considerable sacrifices to balance administrative duties and their teaching load. In response to a question on how HoDs balance their administration and their teaching load, the HoD at School C said,

Eish, it's tough but we try to balance. We usually do administrative work in the afternoon. It needs some sacrifice. Usually we as HoD's, we remain here when the school knocks off at fourteen thirty in the afternoon. We usually remain behind until 15:30. Yeah until 15:30. We sacrifice one hour most of the time so that we can do admin work. Because there is not much time to do admin work and also teach. So we try, we sacrifice our time. (HoD, School C)

Tapala et al. (2020) and Jacobs et al. (2016) agree that HoDs face challenges, including time constraints, as they maneuver between administrative tasks and their teaching workloads. They are often required to work extra hours and during weekends, which sometimes leads to burnout and which could have a knock-on effect on the quality of their work.

\subsection{Teacher professional development}

The inadequate capacity of teachers appointed to senior positions (Mbhalati \& Jita, 2018), renders teacher professional development a fundamental tool to close existing gaps and to ensure efficacy. Teacher professional development enables teachers to acquire new skills (Du Plessis, 2016) and to enhance their competence 
and confidence (Harris, 2003), which leads to effective curriculum implementation (Syomwene, 2018). In addition to guiding new teachers about a school's culture, it improves learner performance, motivates teachers, and guarantees job satisfaction (Syomwene, 2018). In an environment where effective distributed leadership prevails, teacher professional development becomes part of the core functions of the HoD. Schools B and D had school cultures that warranted HoDs to develop new teachers professionally:

Yeah, you see that's part of the school's culture, so mainly the head of the department...will be involved in orientating the new staff members, various science teachers, and through that, we are upholding the culture of science in our schools through the younger teachers. We try to develop them well. (Principal, School B)

If the teacher is new, they [HoDs] must orientate that teacher; they must show what is expected from the teacher and how everything is going on...the HoDs must ensure that the teacher preparation is well conducted. (Deputy Principal, School D)

Although professional development is not a novel practice in South African high schools, Ajani (2019) endorses the need for proper structuring to ensure its efficacy in all school contexts, so that it meets the needs of individual teachers in the classroom.

Furthermore, in the view of the physical science teacher at School A, teacher professional development empowers teachers widely by covering different aspects, based on individual needs. For example, training could assist teachers to develop the types of questions in which they are deficient and in which they need assistance. In the process, HoDs can identify unexploited teacher potentials and they can provide professional development to assist them in developing to their full potential. The science teacher at School A clarified that "sometimes the development is quite good which means that they have the ability, but they are not spending a lot of time studying to know the basics." In this case, the applicable professional development approach should aim to improve the classroom practice of the teachers concerned. In a Ghanaian study, Abreh (2018) found that, when teachers have professional development opportunities that could ameliorate existing challenges, teaching and learning in science and mathematics are likely to improve.

Additionally, HoDs engaged in follow-up sessions with teachers after class visits to provide professional development in response to challenges that they observed. This resulted in the improvement of classroom practices and learner performance (Musyoka et al., 2017). The science HoD at School B said, "I discuss my visit with the teachers ... , we sit around the table and I just say I saw that maybe you can do better, maybe you can teach the subject in this manner or this and that."

In the same vein, the school principal at School A explained how the HoD, as an instructional leader in the distributed leadership framework, conducted quality 
evaluations, and assessed teachers to identify possible challenges for improvement. Teacher evaluation forms completed after class visits provided feedback that guided HoDs in formulating the necessary support to teachers (Mpisane, 2015). Classroom observations that are followed by feedback and reflection sessions (Nel \& Luneta, 2017, p. 4) are developmental for teachers. In alignment, Abreh (2018) reported that interaction with teachers allow HoDs to gather first-hand information that assists with critical decision-making aimed at school improvement and change (Harris, 2009).

\section{Conclusion}

This paper explored the roles played by HoDs in advancing science and mathematics teaching and learning through the distributed leadership framework at selected South African high schools. The evidence reveals that the roles played by science and mathematics HoDs in high schools assisted in maintaining the principles of distributed leadership, such as accountability, which is instrumental in ensuring effective teaching and learning opportunities. Some of the findings align and/or confirm some of the literature used in this study, but with a focus on science and mathematics teaching and learning. The HoDs were engaged in guiding curriculum implementation, monitoring instruction, forging collaboration among teachers, identifying teacher needs, and providing professional development opportunities to enhance science and mathematics teaching and learning. These actions of HoDs were mindful of the need for guided teacher autonomy in the classroom. Since HoDs are subject specialists in the disciplines that they head, they possess the competency to identify teacher challenges and to provide the necessary assistance employing problem-targeted professional development opportunities. Although they faced time constraints caused by their teaching and administrative workload, HoDs managed to maneuver the terrain to perform their duties as instructional leaders. The implementation levels of distributed leadership in South African schools are probably affected by contextual factors that lead to a variation in HoDs' experiences as instructional leaders. Thus, this paper recommends further research to explore the roles played by HoDs in various school contexts to create opportunities for science and mathematics teaching and learning. More evidence will offer a more holistic picture of HoDs' opportunities and challenges as instructional leaders in the context of distributed leadership.

\section{References}

Abreh, M. K. (2018). Heads of departments' perception of teachers' participation in continuous professional development programmes and its influence on science and mathematics teaching in Ghanaian secondary schools. African Journal of Educational Studies in Mathematics and Sciences, 14, 85-99. Retrieved from https://www.ajol.info/index.php/ajesms/article/view/174174

Ajani, O. A. (2019). Effective teachers' cluster system as an approach to enhanced classroom practices in South African high schools. Journal of Gender, Information and Development in Africa (JGIDA), 8(1), 173-194. https://doi.org/10.31920/20504284/2019/8n1a8

Ampofo, S. Y, Onyango, G. A., \& Ogola, M. (2019). Influence of school heads' direct supervision on teacher role performance in public senior high schools, Central 
Region, Ghana. IAFOR Journal of Education, 7(2), 9-26. https://doi.org/10.22492/ije.7.2.01

Ankoma-Sey, V. R., \& Maina, B. (2016). The role of Effective Supervision on academic performance of senior high schools in Ghana. Journal of Arts and Humanities, 5(4), 73-83. http://dx.doi.org/10.18533/journal.v5i4.932

Atieno, O. E., Jotham, O., \& Onyango, A. (2018). Perceptions of principals, heads of departments and teachers regarding effectiveness of principals' instructional supervision in assisting teachers in the implementation of the curriculum. European Journal of Education Studies, 5(7), 173-187. doi: 10.5281/zenodo.2218577

Bambi, A. (2012). The role of head of departments as instructional leaders in secondary schools: implications for teaching and learning. (Doctoral dissertation, University of Johannesburg, Johannesburg, South Africa).

Bipath, K., \& Nkabinde, M. (2018). The motivational roles of heads of department in learners' performance and quality of schooling in South Africa. South African Journal of Childhood Education, 8(1), 1-8. http://dx.doi.org/10.4102/sajce.v8i1.460

Botha, R. J., \& Triegaardt, P. K. (2014). Distributed leadership towards school improvement: Case study in South African schools. International Journal of $\begin{array}{llll}\text { Educational } & \text { Sciences, 309-317. }\end{array}$ https:// doi.org/10.1080/09751122.2014.11890193

Bush, T. (2018a). Prescribing distributed leadership: Is this a contradiction? Educational Management Administration $\mathcal{E} \quad$ Leadership, 46(4), 535-537. https:// doi.org/10.1177/1741143218768403

Bush, T. (2018b). Conceptions of the Leadership and Management of Schools as Organizations. In M. Connolly, D. H, Eddy-Spicer, C. James, \& S. D. Kruse (Eds.), The SAGE Handbook of School Organization, 51-66. London: Sage publications.

Christie, P., Sullivan, P., Duku, N., \& Gallie, M. (2010). Researching the need: School leadership and quality of education in South Africa. Report prepared for Bridge, South Africa: Ark, UK. Retrieved from http://www.bridge.org.za/wpcontent/uploads/2014/12/School-leadership-Report-on-Quality-SchoolLeadership-Aug-2010.pdf

Creswell, J. W. (2014). A concise introduction to mixed methods research. Thousand Oaks, CA: Sage.

De Lima, J. A. (2008). Department networks and distributed leadership in schools. School $\begin{array}{lll}\text { Leadership } \text { and } & \text { 159-187. }\end{array}$ https://doi.org/10.1080/13632430801969864

Du Plessis, A. (2016). South African heads of department on their role in teacher development: Unexpected patterns in an unequal system. In N. Popov, C. Wolhuter, J. Kalin, G. Hiton, J. Ogunleye, \& E. Niemcyk (Eds.) Education provision to everyone: Comparing perspectives from around the world. BCES Conference Books, 14(1), 113-119. Bulgaria: Bulgarian Comparative Education Society. Retrieved from https://bib.irb.hr/datoteka/824891.BCES_Conference_Book_2016_Vol_14_No_ 1_text.pdf\#page $=113$

Du Plessis, A., \& Eberlein, E. (2018). The role of heads of department in the professional development of educators: A distributed leadership perspective. Africa Education Review, 15(1), 1-19. https://doi.org/10.1080/18146627.2016.1224583

Durrani, N., \& Tariq, V. N. (2012). The role of numeracy skills in graduate employability. Education + Training, 54(5), 419-434. Retrieved from https://www.emerald.com/insight/content/doi/10.1108/00400911211244704/f ull/html 
Farchi, T., \& Tubin, D. (2019). Middle leaders in successful and less successful schools. School Leadership and Management, 39(3-4), 372-390. https://doi.org/10.1080/13632434.2018.1550389

Grant, C. (2006). Emerging voices on teacher leadership: Some South African views. Educational Management Administration and Leadership, 34(4), 511-532. https://doi.org/10.1177/1741143206068215

Harris, A. (2003). Distributed leadership in schools: leading or misleading? Management in Education, 16(5), 10-13. Retrieved from https://journals.sagepub.com/doi/pdf/10.1177/089202060301600504

Harris, A. (2005). Distributed leadership. In Davies B. (Ed.) The essentials of school leadership (pp. 160-172). Thousand Oaks, CA: Sage.

Harris, A. (2009). Distributed leadership: What we know. In: Harris A. (Ed.) Distributed leadership: Different perspectives (pp. 11-21). Dordrecht: Springer.

Harris, A. (2013). Distributed leadership: Friend or foe? Educational Management Administration and Leadership, 41(5), 545-554. https://doi.org/10.1177/1741143213497635

Harris, A., \& Spillane J. (2008). Distributed leadership through the looking glass. Management in Education, 22(1), 31-34. Retrieved from https://journals.sagepub.com/doi/pdf/10.1177/0892020607085623

Harris, A., Day, C., Hopkins, D., Hadfield, M., Hargreaves, A., \& Chapman, C. (2013). Effective leadership for school improvement. London: Routledge.

Hsieh, H. F., \& Shannon, S. E. (2005). Qualitative health research. Three approaches to qualitative content analysis. Qualitative Health Research, 15(9), 1277-1288. https://doi.org/10.1177/1049732305276687

Jacobs, J., Gordon, S. P., \& Solis, R. (2016). Critical issues in teacher leadership: A national look at teachers' perception. Journal of School Leadership, 26(3), 374-406. https:// doi.org/10.1177/105268461602600301

Kirori, M., \& Dickinson, D. (2020). Not a panacea, but vital for improvement? Leadership development programmes in South African schools. South African Journal of Education, 40(1), 1-11. https://orcid.org/0000-0003-2238-1214

Leithwood, K, Harris, A., \& Hopkins, D. (2020). Seven strong claims about successful school leadership revisited. School Leadership and Management, 40(1), 5-22. https://doi.org/10.1080/13632434.2019.1596077

Ma, X., \& Marion, R. (2019). Exploring how instructional leadership affects teacher efficacy: A multilevel analysis. Educational Management Administration and Leadership, 1-20. https://doi.org/10.1177/1741143219888742

Mashapa, N. F. (2019). Mathematics heads of departments as instructional leaders in Limpopo secondary schools. (Doctoral dissertation, University of Pretoria, Pretoria, South Africa). Retrieved from http://hdl.handle.net/2263/71717

Mathers, N., Fox, N., \& Hunn, A. (1998). Using interviews in a research project. Sheffield: Trent Focus Group.

Mbhalati, N. B., \& Jita, L. C. (2018). School-based instructional leaders and their capacity to lead literacy instruction in the foundation phase. Journal of Educational Studies, 17(2), 105-120. Retrieved from https://journals.co.za/docserver/fulltext/jeds_v17_n2_a8.pdf?expires=1597352 038\&id=id\&accname $=57783 \&$ checksum=3F04D9ED858DD8C18499AF2FD3AC6 25B

McLean, A. (2013, February 15). Distributive leadership has four key principles. The Times Educational Supplement Scotland 2304. Retrieved from https:// search.proquest.com/openview/cfef34719a9d743b3257d3b34dde0ba9/1 ?pq-origsite $=$ gscholarandcbl $=366363$ 
Mncube, V. (2009). Perceptions of the principal's role in the democratic governance in South Africa. Journal of Educational Administration and History, 41(1), 29-43. https://doi.org/10.1080/00220620802604594

Mokoena, S. (2011). Participative decision-making: Perceptions of school stakeholders in South Africa. Journal of Social Sciences, 29(2), 119-131. https://doi.org/10.1080/09718923.2011.11892962

Mokoena, S. (2017). Analysis of the roles and leadership capacity of heads of departments in secondary schools. International Journal of Management in Education, 11(3), 284-310. https://doi.org/10.1504/IJMIE.2017.084936

Mpisane, B. (2015). The role of high school heads of department as leaders of learning. (Master's thesis, University of KwaZulu Natal, Durban, South Africa). Retrieved from http://hdl.handle.net/10413/13760

Munje, P. N. (2018). The impact of teacher professional conduct on learner experiences and performance in poor school communities in South Africa. Compare: A Journal of Comparative and International Education, 49(4), 511-528. https:// doi.org/10.1080/03057925.2018.1429253

Musyoka, J. M., Maithya, R., \& Cheloti, S. K. (2017). Influence of head teachers' supervisory role on students' performance in KCSE in public secondary schools in Kathiani sub-county, Machakos County, Kenya. The International Journal of Humanities and Social Studies, 5(12), 170-177. Retrieved from http://theijhss.com/wp-content/uploads/2018/01/24.-HS1712-045.pdf

Naicker, S. R., \& Mestry, R. (2013). Teachers' reflections on distributive leadership in public primary schools in Soweto. South African Journal of Education, 33(2), 1-15. https:// doi.org/10.4018/978-1-4666-6591-0.ch013

Nel, B., \& Luneta, K. (2017). Mentoring as professional development intervention for mathematics teachers: A South African perspective. Pythagoras, 38(1), 1-9. https:// doi.org/10.4102/pythagoras.v38i1.343

Ogina, T. A., (2017). How heads of departments understand their roles as instructional leaders: A South African study. International Journal of Educational Sciences, 18(13), 224-230. https://doi.org/10.1080/09751122.2017.1352573

Patterson, J. A., AlSabatin, H., Anderson, A., Klepacka, M., Lawrence, J., \& Miner, B. (2020). A distributed leadership perspective on implementing instructional reform: A case study of an urban middle school. Journal of School Leadership, 1-20. https://doi.org/10.1177/1052684620904942

Raelin, J. A. (Ed.). (2016). Leadership-as-practice: Theory and application. New York: Routledge.

Rosenfeld, P., Ehrich, L. C., \& Cranston, N. (2009). Changing roles of heads of department: A Queensland case. In P. Jeffery (Ed.), Proceedings of the Australian Association for Research in Education (AARE) 2008 International Research Conference. Changing climates: Education for sustainable futures (pp. 1-17). Brisbane, Australia: The Australian Association for Research in Education, Queensland University of Technology. Retrieved from https://eprints.qut.edu.au/19129/

Samancioglu, M., Baglibel, M., \& Erwin, B. J. (2020). Effects of distributed leadership on teachers' job satisfaction, organizational commitment and organizational citizenship. Pedagogical Research, 5(2), 1-9. https://doi.org/10.29333/pr/6439

Seobi, B. A., \& Wood, L. (2016). Improving the instructional leadership of heads of department in under-resourced schools: A collaborative action-learning approach. South African Journal of Education, 36(4), 1-14. https://doi.org/10.15700/saje.v36n4a1326

Sibanda, L. (2017). Understanding distributed leadership in South African schools: Challenges and prospects. Issues in Educational Research, 27(3), 567- 581. 
Retrieved

from

https:/ / search.informit.com.au/documentSummary;dn=009011116124431;res=I ELAPA

Spillane J. P., Halverson R., \& Diamond J. B. (2004) Towards a theory of leadership practice: A distributed perspective. Journal of Curriculum Studies, 36(1): 3-34.

Spillane, J. P. (2006). Distributed leadership. San Francisco, CA: Jossey-Bass.

Spillane, J. P., Halverson, R., \& Diamond, J. B. (2001). Investigating school leadership practice: A distributed perspective. Educational Researcher, 30(3), 23-28. https://doi.org/10.3102/0013189x030003023

Syomwene, A. (2018). Effective school indicators for quality curriculum implementation process. African Journal of Education, Science and Technology, 4(3), 150-159. Retrieved from http://ajest.info/index.php/ajest/article/view/116

Taole, M. J. (2013). Exploring principals' role in providing instructional leadership in rural high schools in South Africa. Studies of Tribes and Tribals, 11(1), 75-82. https://doi.org/10.1080/0972639X.2013.11886668

Tapala, T. T., Van Niekerk, M. P., \& Mentz, K. (2020). Curriculum leadership barriers experienced by heads of department: a look at South African secondary schools. International Journal of Leadership in Education, 1-18. https:// doi.org/10.1080/13603124.2020.1740796

Thorpe, R., Gold, J., \& Lawler, J. (2011). Locating distributed leadership. International Journal of Management Reviews, 13(3), 239-250. https://doi.org/10.1111/j.14682370.2011.00303.x

Tsakeni, M., \& Jita, L. C. (2017). Followership and sustainability of school leadership for Science and Mathematics: A distributive perspective. Journal of Education (University of KwaZulu-Natal), (69), 237-256. Retrieved from http://www.scielo.org.za/pdf/jed/n69/11.pdf

Vanblaere, B., \& Devos, G. (2018). The role of departmental leadership for professional learning communities. Educational Administration Quarterly, 54(1), 85-114. https://doi.org/10.1177/0013161X17718023

Van Ameijde, J. D., Nelson, P. C., Billsberry, J., \& Van Meurs, N. (2009). Improving leadership in higher education institutions: A distributed perspective. Higher Education, 58(6), 763-779. https://doi.org/10.1007/s10734-009-9224-y

Weller Jr, L. D. (2001). Department heads: The most underutilized leadership position. NASSP Bulletin, 85(625), 73-81. https://doi.org/10.1177/019263650108562508

Zhang Y., \& Wildemuth B. M. (2009). Unstructured interviews. In B. Wildemuth (Ed.), Applications of Social Research Methods to Questions in Information and Library Science (pp. 222-231). Westport, CT: Libraries Unlimited.

Zuze, T. L., \& Juan, A. (2018). School leadership and local learning contexts in South Africa. Educational Management Administration and Leadership, 48(3), 459-477. https://doi.org/10.1177/1741143218814006 